\title{
PEMANFAATAN BIOBRIKET DARI BONGKOL JAGUNG SEBAGAI ENERGI ALTERNATIF
}

\author{
UTILIZATION OF BIOBRICKET FROM CORN COMB AS ALTERNATIVE ENERGY
}

\author{
Indah Pratiwi \\ Program Studi Teknik Analisis Laboratorium Migas Politeknik Akamigas Palembang, 30257, Indonesia \\ Corresponding Author E-mail: indahpratiwikimia@gmail.com
}

\begin{abstract}
This study aims to determine the quality of briquettes from different biomass raw materials namely corncobs. Utilization of the corncob in the biomass energy sector is still not optimal, making the initial thought of the research. In addition, this raw material contains lignicellulose which has the opportunity to be used as raw material for biomass, especially briquettes. The research method used was experimental with the research procedure was the manufacture of briquettes then the products were analyzed. The adhesive composition used is $5 \%$ of the main ingredient. The adhesive used is starch. The quality of briquettes is tested including moisture content, ash content, volatile, and calorific value. The results of the testing of water content, ash content, volatile content, calorific value of corncob charcoal briquettes respectively, namely, moisture content $3.62 \%$ ash content $4.84 \%$ volatile content $11.75 \%$ Calorific value $5,653.99 \mathrm{cal} / \mathrm{g}$. From the results of the analysis, charcoal briquettes have met SNI standards as fuel and are suitable for use as a substitute for alternative fuels.
\end{abstract}

Keywords: Biomass, Quality of Briquettes, Calorific Value

\begin{abstract}
Abstrak: Penelitian ini bertujuan untuk mengetahui kualitas briket dari bahan baku biomassa yang berbeda yaitu bonggol jagung. Pemanfaatan yang masih belum maksimal dari bonggol jagung di bidang energi biomassa menjadikan pemikiran awal penelitian. Selain itu, bahan baku ini mempunyai kandungan ligniselulosa yang berpeluang untuk dijadikan bahan baku biomassa khususnya briket. Metode penelitian yang digunakan adalah eksperimen dengan prosedur penelitiannya adalah pembuatan briket kemudian produknya dianalisis. Komposisi perekat yang digunakan sebesar 5\% dari bahan utama. Perekat yang digunakan adalah tepung kanji. Briket diuji kualitasnya meliputi kadar air, kadar abu, volatile, dan nilai kalor. Hasil pengujian kadar air, kadar abu, kandungan volatile, nilai kalor dari briket arang bonggol jagung berturut-turut yaitu, kadar air 3,62\% kadar abu 4,84\% kandungan volatile 11,75\% Nilai kalor 5.653,99 kal/g. Dari hasil analisis tersebut, briket arang telah memenuhi standar SNI sebagai bahan bakar dan layak digunakan sebagai pengganti bahan bakar alternatif.
\end{abstract}

Kata kunci : Biomassa, Kualitas briket, Nilai Kalor.

\section{PENDAHULUAN}

Jagung (Zea Mays L.) merupakan tanaman monokotil semusim yang menjadi bahan pangan pokok di Indonesia setelah beras. Tanaman jagung mempunyai banyak manfaat di bidang olahan pangan manusia maupun ternak. Minat akan konsumsi jagung semakin tahun semakin meningkat. Data dari Badan Pangan Statstik, ada tiga lapangan usaha paling dominan dalam mendorong ekonomi Indonesia triwulan I/2018. Tanaman pangan padi dan jagung tumbuh ekspansif $94,08 \%$ yang mengalami panen raya (BPS, 2018). Olahan jagung selain memberikan manfaat juga memberikan pekerjaan rumah khususnya bagi para petani jagung. Keluhan para petani jagung dirasa saat melakukan observasi di dua wilayah yang berbeda, yaitu Desa Banteran, Kabupaten Banyumas dan Desa Mentasan, Kabupaten Cilacap. Keluhannya adalah penumpukan limbah jagung yang masih belum teratasi maksimal. Limbah jagung merupakan limbah organik yang jika diolah dengan maksimal dapat memberikan manfaat banyak dan menambah income perekonomian. Salah satunya adalah energi alternatif briket.

\section{TEORI DASAR}

Produk energi alternatif briket dapat memanfaatkan limbah jagung dan daun sebagai komponen utamanya. Kriteria yang harus dimiliki suatu tanaman menjadi bahan bakar energi adalah kandungan selulosa. 
Semua bahan yang mengandung lignit dan selulosa dapat di densifikasi (Sharma, dkk., 2015). Densifikasi adalah proses pengepresan. Selama proses densifikasi, partikel menyusun ulang sendiri pembentukan massa secara keseluruhan dimana sebagian besar partikel tetap sebagian besar mempertahanka sifat asli mereka, meskipun energinya hilang (Frodeson dkk., 2019). Bonggol jagung memiliki kandungan selulosa $42 \%$, hemiselulosa $33 \%$, lignin $18 \%$, abu $1,5 \%$ dan $5,5 \%$ bahan lain (Schwietzke, dkk., 2009).

Pemanfaatan limbah bonggol jagung menjadi briket tentunya akan membawa angin segar khususnya petani jagung. Berdasarkan metode pembuatannya, briket terbagi menjadi dua jenis yaitu briket bioarang dan biobriket. Briket bioarang dibuat melalui proses pengarangan dari bahan utama sedangkan biobriket tidak melalui proses pengarangan. Briket dengan kualitas yang baik memiliki sifat seperti tekstur yang halus, tidak mudah pecah, keras, penyalaan yang baik, aman bagi manusia dan lingkungan (Jamilatun, 2008). Oleh karena itu, briket yang berkualitas minimal memenuhi standar yang telah ditetapkan (SNI 01-6235- 2000). Komponen yang harus dipenuhi antara lain, nilai kalor $\geq$ $5.000 \mathrm{kal} / \mathrm{g}$, kadar abu yang dihasilkan maksimal $8 \%$, kadar air maksimal $8 \%$, volatile yang hilang pada pemanasan $950^{\circ} \mathrm{C}$ maksimal $15 \%$. Diantara kedua briket yang dihasilkan, briket bioarang memiliki kualitas lebih tinggi dibanding biobriket (Sulistyaningkarti, dkk., 2017).

Tujuan penelitian ini adalah menganalisis perbandingan kualitas tingkat energi kalor, kadar air, kadar abu, volatile dari briket bonggol jagung. Hasil perbandingan ini digunakan untuk penelitian lanjutan dalam mencari komposisi terbaik bahan baku briket dari bonggol jagung.

\section{METODOLOGI PENELITIAN}

\section{a. Metode Penelitian}

Metode penelitian yang digunakan adalah metode eksperimen comparative, dengan dua sampel yaitu bonggol jagung dengan komposisi perekat yang digunakan sebesar $5 \%$.

\subsection{Pengumpulan Data}

Pengumpulan data didapat melalui tiga tahap uji sampel dari briket. Prosedur pembuatan briket bioarang dapat terlihat pada gambar berikut.

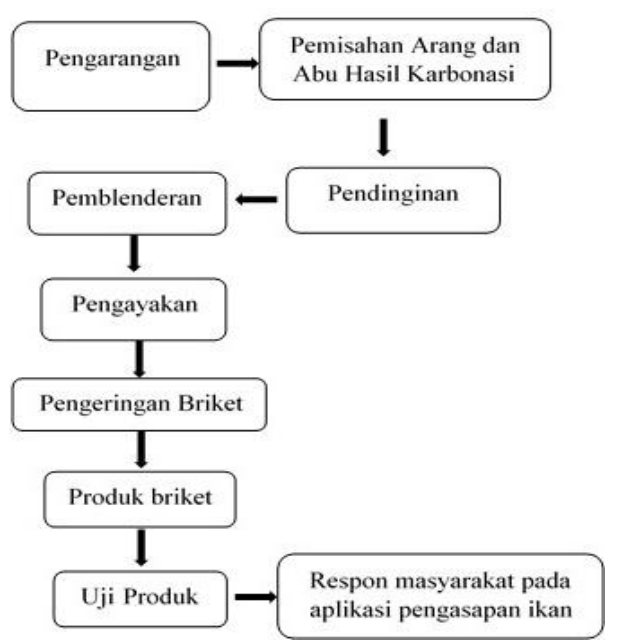

Gambar 3.1 Bagan Alir Proses Pembuatan Briket dari Bonggol Jagung

\section{HASIL DAN PEMBAHASAN}

\subsection{Kadar Air}

Kadar air suatu briket dikatakan baik jika tidak lebih dari 8\%. Semakin sedikit kadar air yang dikandung suatu briket maka kualitas briket tersebut semakin bagus. Kandungan kadar air briket dipengaruhi oleh luas permukaan pori-pori arang dan kadar karbon terikat yang terdapat pada briket (Kahariayadi, dkk., 2015). Hasil kadar air briket arang bonggol jagung sebesar 6,23\% briket tersebut memenuhi standar karena di bawah $8 \%$.

\subsection{Kadar Abu}

Sesuai standar SNI kadar abu yang harus dimiliki briket tidak lebih dari $8 \%$. Semakin kecil nilai kadar abu, semakin bagus kualitas briket. Hal ini karena jika kadar abu tinggi mengartikan briket tersebut mengandung silika yang tinggi juga. Unsur silika merupakan unsur yang memiliki pengaruh kurang baik terhadap kualitas briket. 
Dari hasil penelitian yang didapat, briket arang bonggol jagung memiliki kadar abu yaitu $4,84 \%$.

\subsection{Volatile Matter}

Kadar volatile dalam briket menunjukkan bahwa saat proses pembakaran dapat dilihat seberapa banyak kadar karbon yang terikat. Kadar karbon bernilai tinggi jika kadar abu, kadar air dan kadar zat menguap briket rendah (Putri, dkk., 2017). Semakin tinggi kadar karbon pada briket, semakin baik kualitas briket tersebut. Tinggi rendahnya kadar zat menguap / volatile matter pada briket di pengaruhi juga oleh waktu dan suhu pada proses pengarangan. Semakin besar suhu dan waktu pengarangan, maka semakin banyak zat menguap terbuang sehingga pada saat pengujian kadar zat menguap akan diperoleh kadar zat menguap yang rendah (Yuliah, dkk., 2017). Dari hasil pengamatan, nilai volatile briket arang bonggol jagung yaitu $25,86 \%$. Hal ini menunjukkan bahwa hasil penelitian ini sudah memenuhi kriteria karena semakin rendah kadar abu semakin tinggi kadar volatile-nya.

\subsection{Nilai Kalor}

Nilai kalor merupakan komponen terpenting dalam menentukan kualitas briket. Jika nilai kalor suatu briket rendah dan tidak memenuhi standar SNI maka dapat dikatakan briket tidak layak untuk digunakan sebagai energi alternatif.. Nilai kalor briket arang daun jati lebih tinggi dibanding dengan nilai kalor briket arang bonggol jagung sebesar 7222,95 $\mathrm{kal} / \mathrm{g}$. Nilai kalor briket tersebut telah memenuhi standar SNI. Artinya, briket arang bongkol jagung dapat menjadi salah satu alternatif.

\section{KESIMPULAN}

Dari hasil analisis, briket arang bonggol jagung layak dijadikan sebagai energi alternatif. Hal ini diperlihatkan dengan nilai yang telah ditetapkan SNI, briket tersebut telah memenuhi standar briket yang layak, digunakan sebagai pengganti bahan bakar alternatif.

\section{DAFTAR PUSTAKA}

Frodeson, S., Henriksson, G., Berghel, J. .2019. Effects of Moisture Content During Densification of Biomass Pellets, Focusing On Polysaccharide Substances. Elsevier: Biomass and Bioenergy, 122, 322-330.

Jamilatun, S. 2008. Sifat-sifat Penyalaan dan Pembakaran Briket Biomassa, Briket Batubara dan Arang Kayu, Rekayasa Proses, 2(2), 3740 .

Kahariayadi, A., Setyawati, D., Nurhaida, Diba, F., Roslinda, E. 2015. Kualitas Arang Briket Berdasarkan Persentase Arang Batang Kelapa Sawit (Elaeis Guineensis Jacq) dan Arang Kayu Laban (Vitex Pubescens Vahl), Hutan Lestari, 3(4), 561-

568.

Lamid, M., Julita, A.F.E., Widjaya, Ng.M.R.. 2013. Inokulasi Bakteri Selulolitik Actinobacillus sp. Asal Rumen pada Daun Jati Menurunkan Serat Kasar dan Meningkatkan Protein Kasar, Jurnal Veteriner, 14 (3), 279284.

Putri, R.E., Andasuryani. 2017. Studi Mutu Briket Arang Dengan Bahan Baku Limbah Biomassa, Jurnal Teknologi Pertanian Andalas, 21(2).

Schwietzke, S., Kim, Y., Ximenes, E., Mosier, N.,and Ladisch, M.. 2009. Ethanol Production from Maize. 